\title{
The Open Secret Of Male Prostitution In The Philippines: A Descriptive Phenomenological Study
}

\author{
Soren R. Sanchez \\ University of Cebu - Main Campus, Philippines
}

Doi:10.19044/esj.2021.v17n15p73

Submitted: 05 April 2021

Accepted: 11 May 2021

Published: 31 May 2021
Copyright 2021 Author(s)

Under Creative Commons BY-NC-ND

4.0 OPEN ACCESS

Cite As:

Sanchez S.R. (2021). The Open Secret Of Male Prostitution In The Philippines: A Descriptive Phenomenological Study.

European Scientific Journal, ESJ, 17(15), 73. https://doi.org/10.19044/esj.2021.v17n15p73

\begin{abstract}
This study attempts to describe the lived experiences of the male teenager and adult sex workers of Cebu City, Philippines in terms of their attitude and behavior, reasons for indulging in prostitution, clientele, challenges, and coping mechanisms. A descriptive phenomenological design with personal interviews and a naturalistic paradigm were used to gather data from the purposely chosen participants. Triangulation was carried to validate the participants' responses. Results show that male teenagers and adult sex workers tend to be covert of their work, neglectful of others' judgment about prostitution, and view prostitution as any other job. Poverty, lack of parental guidance and support, early exposure to pornography, peer pressure, unemployment due to poor educational attainment were their reasons for indulging in prostitution. They catered to random bisexual and transgender clients. They encountered various problems such as awkwardness with their partner, financial instability, public distress, and fear of HIV transmission. Getting motivation from the money as payment, sustaining their own and family's needs were their means of coping up. Resorting into prostitution is a story to tell. Male teenagers and adult sex workers experienced poverty as their common denominator of indulging in prostitution. Though they are condemned by society for entering prostitution they intend to provide and suffice their needs. Prostitution, therefore, is a means to survive amidst living in poverty.
\end{abstract}


Keywords: Male Prostitution, Attitudes, And Behaviour, Reasons, Clientele, Challenges, Coping Mechanism

\section{Introduction}

One of the continually-arising global problems that countries across the world are constantly combating is prostitution (Feingold, 2005; Hudges \& de Compostela, 2004). The term prostitution connotes sexual satisfaction services in exchange for compensation (O'Connell Davidson, 2007). This payment could be monetary (Ditmore, 2006) or in a form of valuables (Edlund $\&$ Korn, 2002). Though this occupation is hazardous by nature (Hayes-Smith \& Shekaharkhar, 2010), Singh and Hart (2007) assert that aplenty of countries from different corners of the world have shifted their view on prostitution from criminal act to asset for tourist attraction. Huisman and Kleemans (2014) confirm that sex tourism is a wide-ranging market.

There are countries where prostitution has evolved from apparently non-existent to organized sex tourism and industry. Hugo (2002) reveals that Thailand, the Philippines, and Indonesia are among Southeast Asian countries where sex tourism is most common. Cunningham and Shah (2018) refute that the legalization or decriminalization of prostitution elevates the cases of human immunodeficiency viruses (HIV) and acquired immune deficiency syndrome (AIDS). In the Philippines, the Department of Health (DOH) released their poll on HIV cases last October 2018. Results pointed out that men who have sex with other men are the highest cases of HIV rate (Department of Health, 2018).

This poll simply reveals that male prostitution is rampant in the Philippines. By definition, male prostitution refers to the act or practice of rendering sexual services among men as compensation for payment (West, 2012). It is an unconventional form of sex work. Although clients can be of any gender, most are male. Compared to female prostitutes, male prostitutes have been far less studied by researchers.

According to the Department of Health (2018) poll in October 2018, there were a total of 1,072 newly diagnosed HIV-positive individuals. Ninetyfive percent of them were male. In terms of mode of transmission, ninetyseven percent acquired HIV through sexual contact. Eighty-six percent of those were male having sex with male.

In accumulated results, from January 1984 to October 2018, there were 2,470 HIV-positive individuals. Sexual contact was the predominant mode of transmission. Fifty-seven percent were males having sexual contact with males. Twenty-one percent were males having sex with both males and females. Eleven percent were males having sex with females. By province, Cebu was ranked as the third-highest HIV rate in the entire archipelago, 
second in the rank was Region 4A while the National Capital Region was ranked as the first predominant place of HIV (Department of Health, 2018).

It is for those pieces of evidence that ignited the researcher to pursue this research. This study attempts to describe the lived experiences of a male teenagers and adult sex workers in Cebu City, Philippines in terms of their attitudes and behavior, reasons for indulging in prostitution, clientele, challenges, and coping mechanisms.

\section{Literature Review}

It has been debated that prostitution equates to human trafficking (Weitzer, 2010). Though it imposes a problem, it is considered a million-dollar business (Edlund \& Korn, 2002). The term prostitution often denotes a crisis of human rights in sexual exploitation among children and women. Outshoorn (2005) justifies that human trafficking is primarily caused by prostitution. Hence, creating laws can regulate prostitution and lessens the criminal offenses of sex trafficking. Aside from human trafficking offenses, prostitution likewise permits the transmission of sexually transmitted diseases such as gonorrhea and HIV (Cunning \& Shah, 2018). In Asia, countries that have high cases of HIV are China, Malaysia, Nepal, Vietnam, and Indonesia, Thailand, Myanmar and India including the Philippines (Kageyama et al., 2009).

Prostitution has now been an asset to some countries, usually termed as sex tourism or sex industry (Mossman, 2007). This phenomenon is rampant in less developing countries (Edlund \& Korn, 2002). To combat this fastgrowing problem, a lot of countries have been debating whether to legalize or decriminalize prostitution. Sullivan (2005) avers that by implementing so, the escalation of prostitution accompanied by human trafficking will be reduced. Farley (2009) affirms that legalizing prostitution reduces human trafficking.

In the Philippines, male prostitution is a predominant reason of its high HIV rate where the main mode of transmission is sexual intercourse (Department of Health, 2018). The terms used for male sex workers differ from females. Some terms may vary by method of business or clientele. In countries where prostitution is illegal or taboo, male sex workers use euphemisms such as body massage, nude modeling, escort, and other feefor-service arrangements. A man who does not consider himself as gay, but who renders sexual services with male clients for money, is called gay-for-pay (Escoffier, 2003). With the advent of the Internet, male sex workers find customer online (Pruitt, 2005). This paved the way to gain new mechanisms for male-to-male prostitution (Bimbi \& Parsons, 2005).

On the other hand, sex workers are victims of their environmental circumstances (Farley \& Kelly, 2000). Individuals who grew up in families and surrounded by neighbourhoods where prostitution was rampant may likely 
end up prostituting. Moreover, unemployment and living in extreme poverty are tempting situations to indulge in prostitution (Bamgbose, 2002). Ditmore (2006) asserts that sex workers are relatively seen as lack of self-esteem and self-worth. This is rooted in the stigmatization of society having been involved in prostitution. This societal stigmatization of prostitution made sex workers vulnerable to physical attacks (Lowman, 2000). Since prostitution is illegal in most places, the transaction happened in the dark streets, where the security of the sex workers against aggressive customers is compromised (Kurtz et al, 2004).

As in any form of the sex industry, male sex workers face risks and problems. These risks include criminal risks and health-related risks like the transmission of sexually transmitted diseases. They are prone to physical abuse and social abuse such and gay-bashing, family, and friend rejection. Likewise, they also suffered financial risks which stem from having an unstable and low income; and the risks of the emotional effects that come from dealing with all of those factors (Farley \& Kelly, 2000).

\section{Methodology}

This study is qualitative. It follows a descriptive phenomenological design. It is a kind of qualitative design that aims to study the actual experiences of people experiencing a phenomenon (Bazeley, 2013). It is not meant to generalize instead to give awareness. The natural paradigm was used in the course of data gathering. It is a phenomenological study type that allows the researcher to investigate and analyze the condition of the purposively selected participants. A one-on-one personal interview was carried out with the male sex workers. To avoid biases and ensure the validity of the participants' responses, two of the participants' close friends served as the validators. The use of triangulation allowed the researcher to cross-check the responses and facilitates the understanding of the complex aspects of the participants' responses.

Purposive sampling aided the researcher in determining the participants of the study. The researcher selected six (6) participants and categorized them into a teenager (ages 18-19) and adult (ages 20-above). The data gathered through interviews conducted in an indoor setting of the local area of Cebu City, Philippines.

The participants of the study were interviewed first followed by their two friends to verify their responses. The interview questions were made in English but translated into vernacular in asking the participants for evident understanding and communication. The researcher made use of a voice recorder. The interview questionnaire was made up of questions that sought to answer the information needed. 


\section{Results and Discussion Demographic Profile}

The study involved six (6) male sex worker participants. They were categorized by age into two (2) namely: teenager and adult. Three (3) or $50 \%$ of the participants were teenagers, and another three (3) or 50\% of them were adults. Teenager participants were 18 to 19 years of age. Adult participants were 21 years of age and above.

Two (2) of the teenager participants were studying at the tertiary level. One (1) teenager participant stopped reporting to school. Two (2) of the adult participants were high school graduates and one (1) adult participant was up to elementary level. All of the teenager participants were financially supported by their parents. All of the adult participants were self-supported.

\section{Attitudes and Behaviour of Male Teenager and Adult Sex Workers}

Male prostitution may cause wide-ranging impacts on the attitudes and behaviour of those who opt to indulge in this activity. Though the Philippine society considers prostitution as an indecent job, few of the participants appeared to disregard the country's standard of living. Despite being prone to ridicule like gay-bashing (Farley \& Kelly, 2000), participants tend to disregard what people might say about them and their job. This was testified by participant 2 under the teenager category and participant 4 under adult category.

"I do not care what people say against me. Besides, they are not helping me; I'm not asking help from them either. I just do not mind them because there is nothing I can do with it."

"I do not really care what they say because they cannot provide me with my needs like food. They cannot also provide me with the things I want. “

Furthermore, one of the participants elicited positive attitudes towards prostitution. Since prostitution becomes an important source of income (Kaye, 2004), sex workers tend to show commitment to their job. They viewed prostitution the same as any other profession since their daily living needs are sustained in this job. This was confirmed by participant 5 , who belongs to the adult category.

" For me, there is no difference between what we are doing from any other jobs. They work hard, we work hard also; they feel tired, we feel tired too. If they are sincere to their work, we are likewise serious so that we can earn income."

Nevertheless, Scott (2003) explains that prostitution was traditionally perceived as a moral problem. Since people perceive prostitution as an improper and derogatory job, some sex workers who tried to be covert with it. As much as possible, they tried to hide it from the public for the reason that 
they are not comfortable with the nature of prostitution. This was manifested by participant 3 under the teenager category.

"People thought that we are shameless but we still feel awkwardness. There are times that we are not comfortable with our work but we still do what we do since it is needed. Sometimes, we try to be covert."

\section{Reasons for Indulging Prostitution of Male Teenager and Adult Sex Workers}

All of the participants asserted that poverty is the main reason why they joined this activity. They revealed that they rarely eat delicious food. There were times that they found it hard to suffice their appetite three times a day. Bamgbose (2002) affirms that poverty is the most driving force among sex workers to enter into prostitution. One participant claimed that he was driven to indulge in prostitution due to poverty and lack of parental care and attention. This was testified by participant 1 , who belongs to the teenager category, and participant 6 , who belongs to the adult category.

"It is really hard when there is no money. No food to eat. We often starve. We individually find ways to eat with my siblings. My mom knows what I am doing. She does not care about it.)

Moreover, peer pressure is also a reason for indulging in prostitution. When an individual has a circle of friends indulging in prostitution, the possibility of ending up prostituting is high (Farley \& Kelly, 2000). Participants have admitted that almost all of their friends find income in prostitution. Seeing them buying delicious food, wearing presentable clothes, and having extra money are great temptations to indulge in prostitution. This was manifested by participant 2 , who belongs to the teenager category.

"This is also the means of getting an income among my friends.

They told me to try so that I get money but I refused it at first. However, seeing them having lots of money, buying delicious foods and nice clothes, I was convinced to try. “

Philippines and Thailand are the epicenters of the sex industry and international sex tourism in Southeast Asia where the sex workers ' reasons for entering prostitution is economical need (Tagliacozzo, 2008). Having poor educational attainment and unemployment likewise lead to prostitution. The companies nowadays do not simply hire applicants with poor educational attainment, that even janitorial position requires college level. Thus, those with low educational attainment resorted to indulging in prostitution. This was manifested by participant 4 under the adult category.

"It is really hard to find a job nowadays. If my cousin was not hired for a janitorial position despite being a high school graduate, how much more to me. I just finished Grade 6. “ 
Nonetheless, while it is quite true that all occupations require sweat and hard work for about a day in exchange for money, some sex workers find their work easier. They bestow sexual and intimate services for few hours only; shorter than other kinds of job. Tomura (2009) corroborates that prostitution is considered an occupation since several individuals are found living on it as depicted in the results of different studies. This was testified by participant 5 under the adult category.

"It is fun sometimes. It is not that exhausting... unlike other jobs, they render service for how many hours while for us, it would just usually take us for few hours only. “

Another factor that leads one to indulge in prostitution is curiosity. One participant revealed that as early as elementary, he was already exposed to nude photos and movies that involve sensual scenes. With this exposure, his interest and clamor to mimic the scenes eventually arose. Farley and Kelly (2000) justify that environmental circumstances fuel one to enter into prostitution. This was evident with the response of participant 2, who belongs to the teenager category.

"When I was young, I already saw nude pictures and movies that have lots of sex scenes. I guess, because of those I started to like it."

\section{Clients of the Male Teenager and Adult Sex Workers}

In recent times, finding customers is done online with the advent of the internet (Pruitt, 2005). Most of the participants revealed that they do not have a regular customer. However, most of their clients are bisexual and transgender. They bestow intimate and sexual services among men for payment (West, 2012). The evidence was manifested by participant 2 under the teenager category.

"We have random customers but most of them are call center agents, maybe because their workplace is just near from our place. Most of them are bisexual and transgender."

\section{Challenges and Coping Mechanism of Male Teenager and Adult Sex Workers}

Male teenagers and adult sex workers encountered various problems. Since our culture viewed prostitution as an indecent job, participants tend to suffer public distress. Some of them were discriminated against due to the nature of their work. Farley and Kelly (2000) elucidate that gay bashing and rejection from friends and family are the common social abuse they experience from indulging themselves in prostitution. They are stigmatized by society (Lowman, 2000). This was testified by participant 1 , who belongs to the teenager category. 
"Discrimination is unavoidable. I have experienced it a couple of times because of the nature of my work. I have nothing to do with that. I do not care at all. “

Moreover, since they aspired to have an intimacy with women, at first they found it awkward to have an intimacy with bisexual and transgender especially if their client looks immensely masculine. The evidence were manifested by participant 3, who belongs to the teenager category, and participant 6 , who belongs to the adult category.

"On my very first try, the feeling was so uncomfortable. The feeling of having sex with a man is so awkward. I was also scared of what might he do to me, knowing that he was more masculine than me. But I got used to it."

"I once had a bald customer. He looks very manly. I guess, he looks more manly than me and it feels so awkward."

Since prostitution is a predominant reason for the transmission of sexually transmitted diseases if not protected (Cunning \& Shah, 2018; Department of Health, 2018), some of the participants also encountered problems like fear of acquiring HIV. Since it is by nature of their work to have different partners every day, it is possible to be contaminated with HIV. Though they prefer using protection, some clients are not satisfied when using it. Additionally, being caught by the police is one of their worries. Street sex workers tend to be covert of their job since they can be arrested by police officers. This occurs in countries where prostitution is illegal and taboo (Farley, 2009). This is testified by participant 1 under the teenager category and participant 5 under the adult category.

"I like to use a condom so that I have protection, but there are some customers who choose not to use a condom. In times like this, I worry to be contaminated with HIV."

"It is never easy to escape and hide from the policemen when they are around. They arrest those prostitutes who find customers on the street. It is like playing hide-and-seek. “

In addition, there were also times that they went home without meeting any customer. Prostitution is seasonal by nature. Because of this, they suffer financial instability. They earn income insconsistently daily, the reason why they suffer financial risks (Farley \& Kelly, 2000). This is testified by participant 4, who belongs to the adult category.

"There are times that we are lucky but there are times as well that there is no customer. We go home without getting something."

Most of the male teenagers and adult prostitutes shared the same coping mechanisms for their problems. Getting motivation from the money they received, clamoring for sustaining both their family and individual needs and wants are their means of coping with their problems. This is manifested 
by participant 2 and 3 under the teenager category and participant 5 who belongs to the adult category.

"At first, I was nervous. I was hesitant if I should continue. I almost gave up but he offered me good amount. I did not anymore complain. My thinking was, what an offer! Where could I get that?"

"Even if I do not like it but when I think about the money I would receive, I feel like doing it. Why not? It is my chance so that I can buy the things I needed plus it is also a big help to my family. “

"I would love to help my family. I made myself open to this kind of work because of my mom. I witnessed her sacrifices for us that she serves other families as a nanny.

Table 1. Summary of the Responses of Male Teenager Sex Workers

\begin{tabular}{|c|c|c|c|c|c|}
\hline $\begin{array}{l}\text { Teenager } \\
\text { Sex Workers }\end{array}$ & $\begin{array}{l}\text { Attitudes \& } \\
\text { Behavior }\end{array}$ & $\begin{array}{l}\text { Reasons for } \\
\text { Indulging } \\
\text { Prostitution }\end{array}$ & Clientele & Challenges & $\begin{array}{l}\text { Coping } \\
\text { Mechanism }\end{array}$ \\
\hline Participant 1 & $\begin{array}{l}\text { Does the job } \\
\text { with } \\
\text { commit- } \\
\text { ment, does } \\
\text { not mind } \\
\text { what people } \\
\text { say }\end{array}$ & $\begin{array}{l}\text { Poverty, less } \\
\text { parental care } \\
\text { and attention }\end{array}$ & $\begin{array}{l}\text { Bisexual and } \\
\text { transgender } \\
\text { call cente } \\
\text { agents }\end{array}$ & \begin{tabular}{l}
\multicolumn{3}{l}{ Awkwardness } \\
towards the \\
client, public \\
distress
\end{tabular} & $\begin{array}{l}\text { Motivation on } \\
\text { money and } \\
\text { sustaining own } \\
\text { \&family's } \\
\text { needs }\end{array}$ \\
\hline Participant 2 & $\begin{array}{l}\text { Does not } \\
\text { mind what } \\
\text { people say }\end{array}$ & $\begin{array}{l}\text { Curiosity, } \\
\text { poverty, peer } \\
\text { pressure, } \\
\text { early } \\
\text { exposure of } \\
\text { nude pictures }\end{array}$ & $\begin{array}{l}\text { Random } \\
\text { bisexual anc } \\
\text { transgender } \\
\text { clients, } \\
\text { mostly cal } \\
\text { center agents }\end{array}$ & $\begin{array}{l}\text { Public distress } \\
\& \text { discrimina- } \\
\text { tion, } \\
\text { financial } \\
\text { problem, }\end{array}$ & $\begin{array}{l}\text { Motivation on } \\
\text { money and } \\
\text { providing one's } \\
\text { wants and } \\
\text { needs }\end{array}$ \\
\hline Participant 3 & $\begin{array}{l}\text { Covert of } \\
\text { his work, } \\
\text { not } \\
\text { comfortable } \\
\text { of his job }\end{array}$ & $\begin{array}{l}\text { Poverty, Peer } \\
\text { Pressure }\end{array}$ & $\begin{array}{l}\text { Random } \\
\text { Bisexual and } \\
\text { Transgender } \\
\text { Clients }\end{array}$ & $\begin{array}{l}\text { Fear of } \\
\text { acquiring HIV, } \\
\text { Financial } \\
\text { problem, } \\
\text { Awkwardness } \\
\text { Towards the } \\
\text { client }\end{array}$ & $\begin{array}{l}\text { Motivation on } \\
\text { money and } \\
\text { supporting } \\
\text { own projects } \\
\text { or outputs in } \\
\text { school }\end{array}$ \\
\hline \multicolumn{6}{|c|}{ Table 2. Summary of the Responses of Male Adult Sex Workers } \\
\hline $\begin{array}{c}\text { Adult } \\
\text { Sex } \\
\text { Workers } \\
\end{array}$ & $\begin{array}{c}\text { Attitudes } \\
\text { \& } \\
\text { Behavior } \\
\end{array}$ & \begin{tabular}{c|c} 
Reasons for \\
Indulging \\
Prostitution
\end{tabular} & Clientele & Challenges & $\begin{array}{c}\text { Coping } \\
\text { Mechanism }\end{array}$ \\
\hline Participant 4 & $\begin{array}{l}\text { Does not } \\
\text { mind what } \\
\text { people say }\end{array}$ & $\begin{array}{c}\text { Poverty, less } \\
\text { job } \\
\text { opportunity } \\
\text { due to poor } \\
\text { educational } \\
\text { attainment }\end{array}$ & $\begin{array}{c}\text { Random } \\
\text { Bisexual } \\
\text { and } \\
\text { Transgender } \\
\text { Clients }\end{array}$ & $\begin{array}{l}\text { Financial } \\
\text { instability, fear } \\
\text { of being caught } \\
\text { by police } \\
\text { officers }\end{array}$ & $\begin{array}{l}\text { Motivation on } \\
\text { money and } \\
\text { providing own } \\
\text { wants and needs }\end{array}$ \\
\hline Participant 5 & $\begin{array}{c}\text { Views } \\
\text { prostitution } \\
\text { as any other }\end{array}$ & $\begin{array}{c}\text { Poverty, } \\
\text { easy access } \\
\text { of money }\end{array}$ & $\begin{array}{c}\text { Random } \\
\text { Bisexual } \\
\text { and }\end{array}$ & $\begin{array}{l}\text { Awkwardness } \\
\text { to the client, } \\
\text { financial }\end{array}$ & Motivation on \\
\hline
\end{tabular}




\begin{tabular}{|c|c|c|c|c|c|}
\hline & $\begin{array}{c}\text { job, Does } \\
\text { not mind } \\
\text { what } \\
\text { people say } \\
\text { enjoying, } \\
\text { early } \\
\text { exposure of } \\
\text { nude } \\
\text { pictures }\end{array}$ & $\begin{array}{c}\text { while } \\
\text { Clients }\end{array}$ & $\begin{array}{c}\text { Transgender } \\
\text { of acquiling } \\
\text { HIV }\end{array}$ & $\begin{array}{c}\text { money and } \\
\text { providing own } \\
\text { wants and needs }\end{array}$ \\
\hline Participant 6 & $\begin{array}{c}\text { Covert of } \\
\text { his work, } \\
\text { not } \\
\text { comfortable } \\
\text { of his job }\end{array}$ & $\begin{array}{c}\text { Poverty, less } \\
\text { job } \\
\text { opportunity } \\
\text { due to poor } \\
\text { educational } \\
\text { attainment }\end{array}$ & $\begin{array}{c}\text { Random } \\
\text { Bisexual } \\
\text { and } \\
\text { Transgender } \\
\text { Clients }\end{array}$ & $\begin{array}{c}\text { Financial } \\
\text { instability, } \\
\text { Awkwardness } \\
\text { to the client, } \\
\text { fear of being } \\
\text { caught by } \\
\text { police officers }\end{array}$ & $\begin{array}{c}\text { Motivation on } \\
\text { money and } \\
\text { providing own \& } \\
\text { family's wants } \\
\text { and needs }\end{array}$ \\
\hline
\end{tabular}

\section{Conclusion}

Resorting into prostitution is a story to tell. Male teenagers and adult sex workers experienced poverty as their common denominator of indulging in prostitution. They shared the same coping mechanism to combat their challenges which to providing their own and family's needs. These intentions made most of them view prostitution as any other job. Though they are condemned by society for entering prostitution they intend to provide and suffice their needs. Prostitution, therefore, is a means to survive amidst living in poverty.

\section{References:}

1. Bamgbose, O. (2002). Teenage prostitution and the future of the female adolescent in Nigeria. International Journal of offender therapy and comparative criminology, 46(5), 569-585.

2. Bazeley, P. (2013). Qualitative data analysis: Practical strategies. Sage

3. Bimbi, D. S., \& Parsons, J. T. (2005). Barebacking among Internetbased male sex workers. Journal of gay \& Lesbian psychotherapy, 9(34),85-105.

4. Cunningham, S., \& Shah, M. (2018). Decriminalizing indoor prostitution: Implications for sexua l violence and public health. The Review of Economic Studies, 85(3), 1683-1715.

5. Department of Health (2018). Newly diagnosed HIV cases. HIV/AIDS \& Art Registry of the Philippines. Retrieved from https://www.doh.gov.ph/sites/default/files/statistics/EB_HIV_Octobe r_AIDSreg2018.pdf

6. Ditmore, M. H. (Ed.). (2006). Encyclopedia of prostitution and sex work (Vol. 1). Greenwood Publishing Group.

7. Edlund, L., \& Korn, E. (2002). A theory of prostitution. Journal of political Economy, 110(1), 181-214. 
8. Escoffier, Jeffrey. "Gay-for-pay: Straight men and the making of gay pornography." Qualitative Sociology 26.4 (2003): 531-555.

9. Farley, M., \& Kelly, V. (2000). Prostitution: A critical review of the medical and social sciences literature. Women \& Criminal Justice, 11(4), 29-64.

10. Farley, M. (2009). Theory versus reality: Commentary on four articles about trafficking for prostitution. In Women's Studies International Forum (Vol. 32, No. 4, pp. 311-315). Elsevier Science.

11. Feingold, D. A. (2005). Human trafficking. Foreign Policy, 26-32.

12. Hayes-Smith, R., \& Shekarkhar, Z. (2010). Why is prostitution criminalized? An alternative viewpoint on the construction of sex work. Contemporary Justice Review, 13(1), 43-55.

13. Hughes, D. M., \& de Compostela, S. (2004, July). Prostitution: Causes and solutions. In Paper delivered at the Conference on Female (pp. 17).

14. Hugo, G. J. (2017). Population mobility and prostitution in Southeast Asia. Moussons. Recherche en sciences humaines sur l'Asie du SudEst, (29), 19-39.

15. Huisman, W., \& Kleemans, E. R. (2014). The challenges of fighting sex trafficking in the legalized prostitution market of the Netherlands. Crime, Law and Social Change, 61(2), 215-228.

16. Kageyama, S., Agdamag, D. M. D., Alesna, E. T., Abellanosa-Tac-An, I. P.,Corpuz, A. C., Telan, E. F. O., \& Ichimura, H. (2009). Tracking the entry routes of hepatitis $\mathrm{C}$ virus as a surrogate of HIV in an HIVlow prevalence country, the Philippines. Journal of medical virology, 81(7), 1157-1162.

17. Kaye, K. (2004). Male prostitution in the twentieth century: Pseudohomosexuals, hoodlum homosexuals, and exploited teens. Journal of Homosexuality, 46(1-2), 1-77.

18. Kurtz, S. P., Surratt, H. L., Inciardi, J. A., \& Kiley, M. C. (2004). Sex work and "date" violence. Violence against women, 10(4), 357-385.

19. Lowman, J. (2000). Violence and the outlaw status of (street) prostitution in Canada. Violence against women, 6(9), 987-1011.

20. Mossman, E. (2007). International approaches to decriminalising or legalising prostitution. New Zealand: Ministry of Justice.

21. O'Connell Davidson, J. (2007). Prostitution. The Blackwell Encyclopedia of Sociology.

22. Outshoorn, J. (2005). The political debates on prostitution and trafficking of women. Social Politics: International Studies in Gender, State and Society, 12(1), 141-155.

23. Pruitt, M. V. (2005). Online boys: male-for-male Internet escorts. Sociological Focus, 38(3), 189-203. 
24. Scott, J. (2003). A prostitute's progress: Male prostitution in scientific discourse. Social Semiotics, 13(2), 179-199.

25. Singh, J. P., \& Hart, S. A. (2007). Sex workers and cultural policy: Mapping the issues and actors in Thailand. Review of Policy Research, 24(2), 155-173.

26. Sullivan, M. (2005). What happens when prostitution becomes work. An Update on Legislation of Prostitution in Australia, Massachusetts, Coalition Against Trafficking in Women Australia.

27. Tagliacozzo, E. (2008). Morphological shifts in Southeast Asian prostitution: the long twentieth century. Journal of Global History, 3(2), 251.

28. Tomura, M. (2009). A prostitute's lived experiences of stigma. Journal of Phenomenological Psychology, 40(1), 51-84.

29. West, D. (2012). Male prostitution. Routledge.

30. Weitzer, R. (2010). The mythology of prostitution: Advocacy research and public policy. Sexuality Research and Social Policy, 7(1), 15-29. 